\title{
照明のデータ。シート No.697
}

一石川県一

日本海側で初めてプロ野球ナイターを可能にした

石川県立野球場の照明
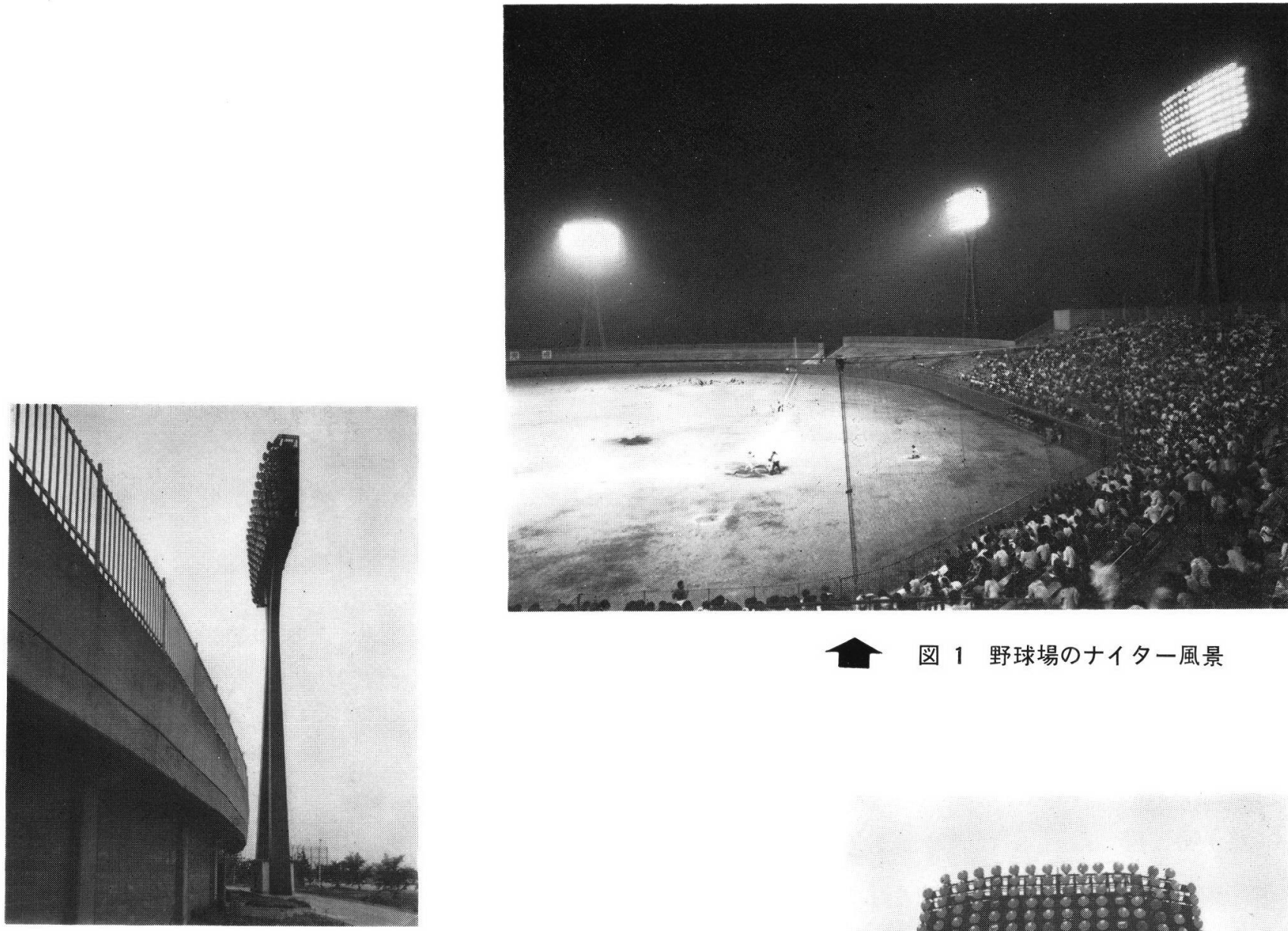

7 図 1 野球場のナイター風景

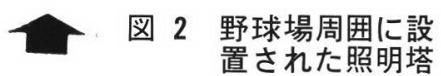
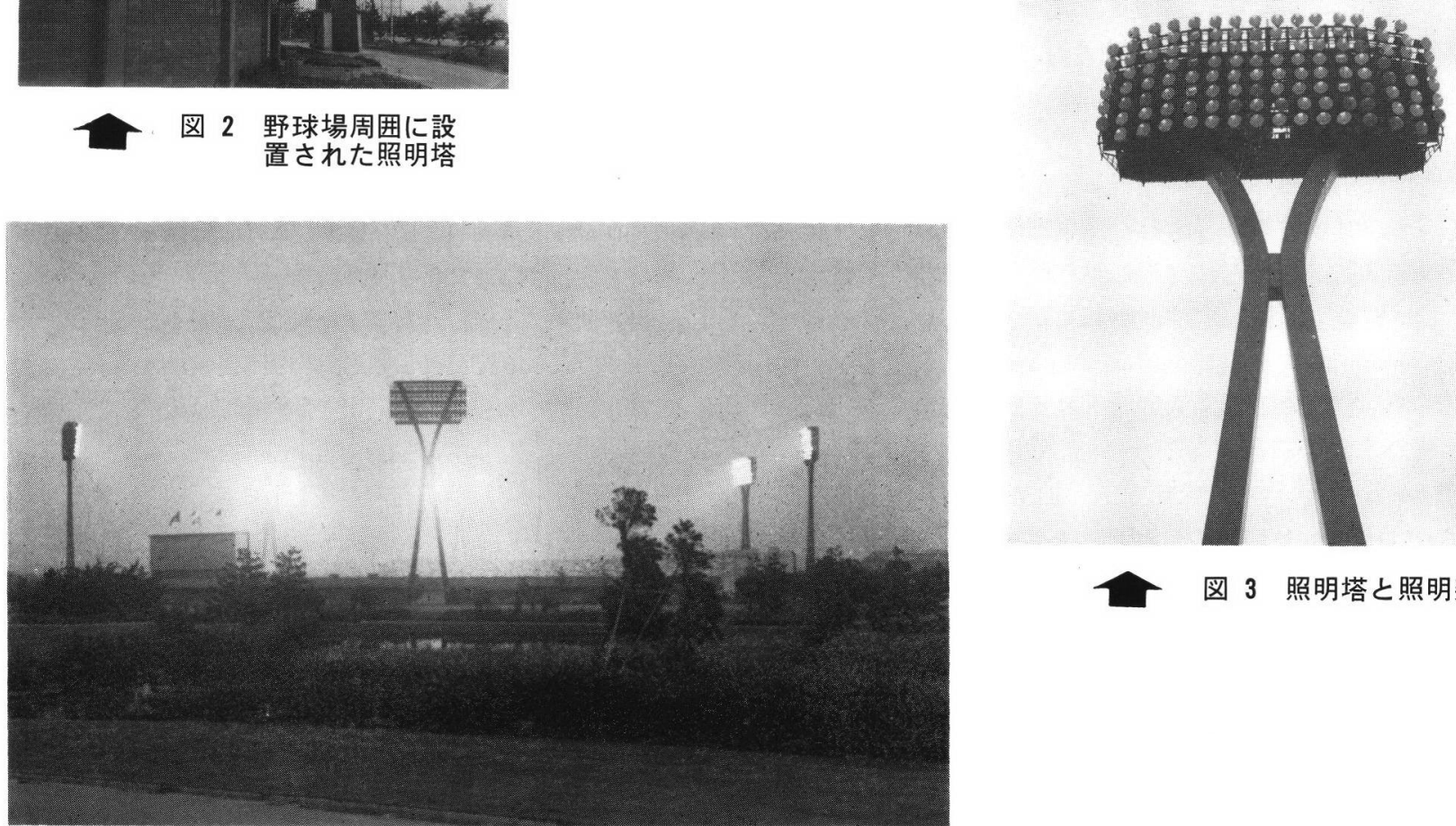

—図 3 照明塔と照明架台

1 図 4 ナイター時の野球場全景 


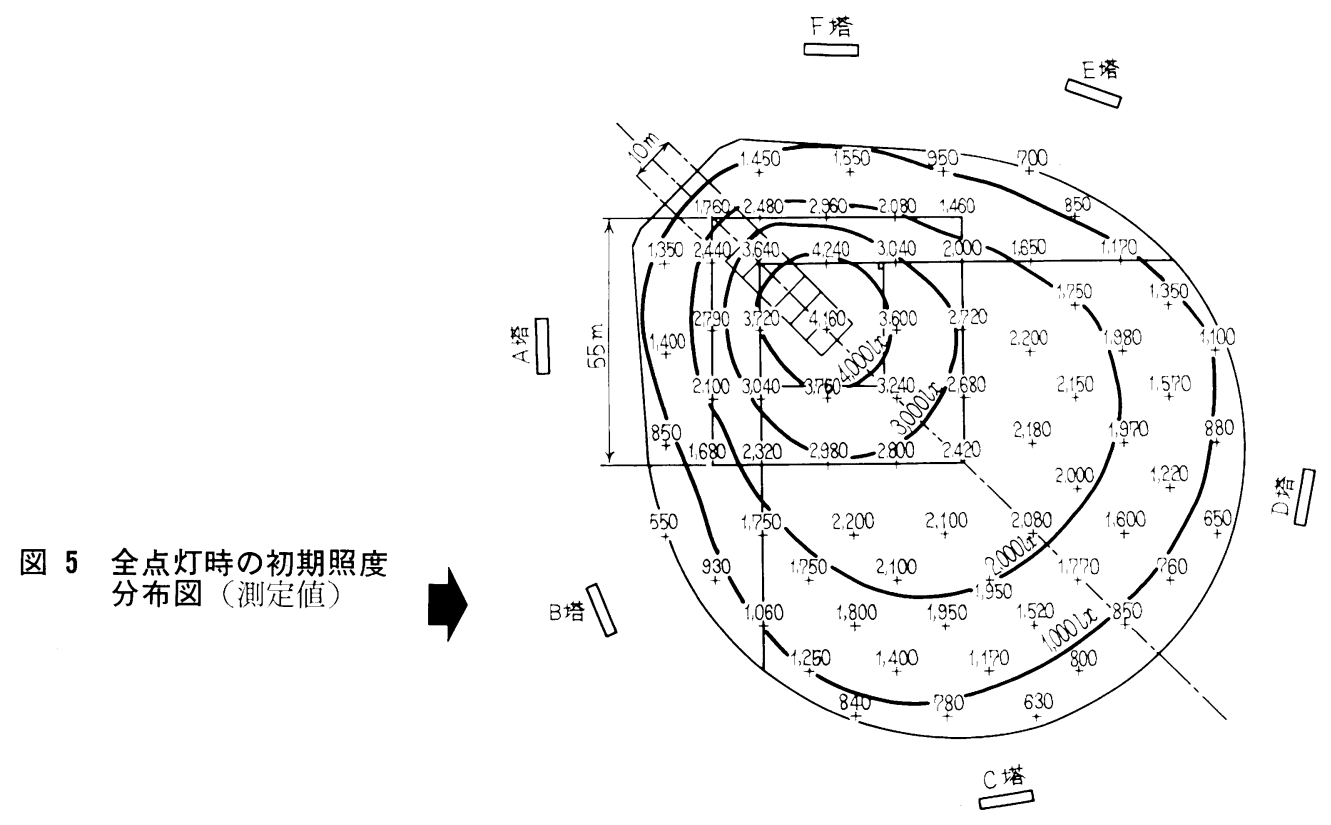

\section{概 要}

金沢方北塚町にある西部緑地公圆队に，炤和 49 年 6 月に 建設された石川県方野球場は，才ープン以来，県民野球の 盛んな北陵の中心都市にふさわしく，連月利用者でにぎわ っている。

同野球場に炤利 56 年6月，日本海側では初めてプロ野球 にも使用できる本格的なナイタ一設備が完成した（図 1〜 図 4).

\section{照 明 設 備}

野球場周囲に，図 2, 図 3 のような 2 本柱化よるスマ 一トなデザインの照明塔（高さ $37.4 \mathrm{~m}$ ) が 6 基設狊されて いる。とく潮風などによるさびを避けるため，照明塔に 壮耐候性鋼板が使用され，投光器，安定器之も耐塩仕様圭 施している。 2 本柱にはさまれた最下部には降圧用トラン ス収納の電気室が設けられ，そこから照明架台部末で柱内 のタラップを登り，保守点検が容易に行なえるようになっ ている.

照明塔架台部には，6基共通でそれぞれ 1 基あたり 660 $\mathrm{W}$ ，水銀灯安定器適合形问压ナトリウムランプ・NH 660 $\mathrm{LX} \ll \mathrm{HL}$-ネオルックス》が38灯, $1 \mathrm{~kW}$ メタルハライド ランプ・M1000B-J/BH 《ネオ八ライドランプ》が 80 灯, $1 \mathrm{~kW}$ 八ロダン電球・J $210 \mathrm{~V} 1,000 \mathrm{~W}$ が 6 灯の計 124 灯が 取り付战秃，6基合部で744灯が使用されている。

高坐:ナリリムランブとメタルハライドランプを組又込 んだ投光器は，超高純度（99.99\%以上）のアルミニウム を反射膜として真空蒸着し，さらに石英透明膜で保護した 反射鏡《シリカブライト》を使用した问效率投光器・HT

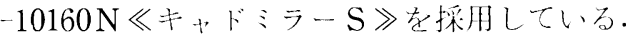

照度の設定は 3 段切替えになっており，プロ野球や公式 戦には全点灯でその他一般使用の場合は $1 / 4$ 点灯で使用さ

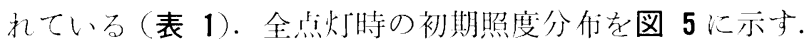
3 種頪の光源による混光照明 $\left(3200 \mathrm{~K}, R_{a}=66\right)$ により, 省录ノで，しか子演色临の優扎た本格的なナイタ一設借之 なって扣り，プロ野球の使用にも十分な明るさが得られて いる。

表 13 段階切り替えによる照度設定パターン（設、値）

\begin{tabular}{|c|c|c|c|c|c|c|}
\hline & & 内 & 野 & 外 & 野 & 平 \\
\hline 金 战 & $k r$ & & $2,000 \mathrm{~lx}$ & & $1,000 \mathrm{~lx}$ & $1,144 \mathrm{~lx}$ \\
\hline $3 / 4$ 点 & 灯 & & 1,500 & & 700 & 850 \\
\hline $1 / 4$ 点 & kJ & & 500 & & 250 & 286 \\
\hline
\end{tabular}

野球場規模

グラウンド面皘 $14,066 \mathrm{~m}^{2}$, 阿翼 $91.5 \mathrm{~m}$

センター距離 $122.0 \mathrm{~m}$

観客保規模

$5,703 \mathrm{~m}^{2}$ (20,600人収容)

所在 地

施主:

監修

石川県

設供設部

石川県土木部党緗課

处築設敦

敇 ムラシマ事務所

丝明設備电気工事

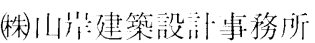

留明設供建築工当 成濑電気工事姝

斎藤建設(怢) 照明器具製作 束勧電材秼

竣工年月

（資料提供 東芝電材秼技術生産本部技術営業センタ一）

専門会員大山敬 


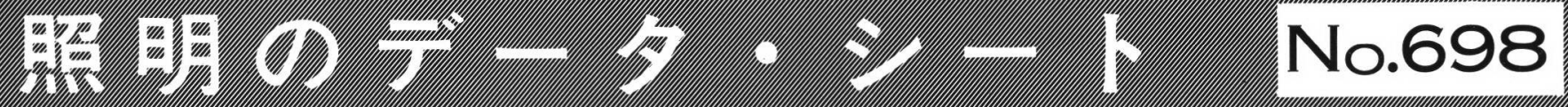

一茨城 県一

$$
\text { メタルハライドランプによる }
$$

\section{国立茨城工業高等専門学校グラウンドの照明}
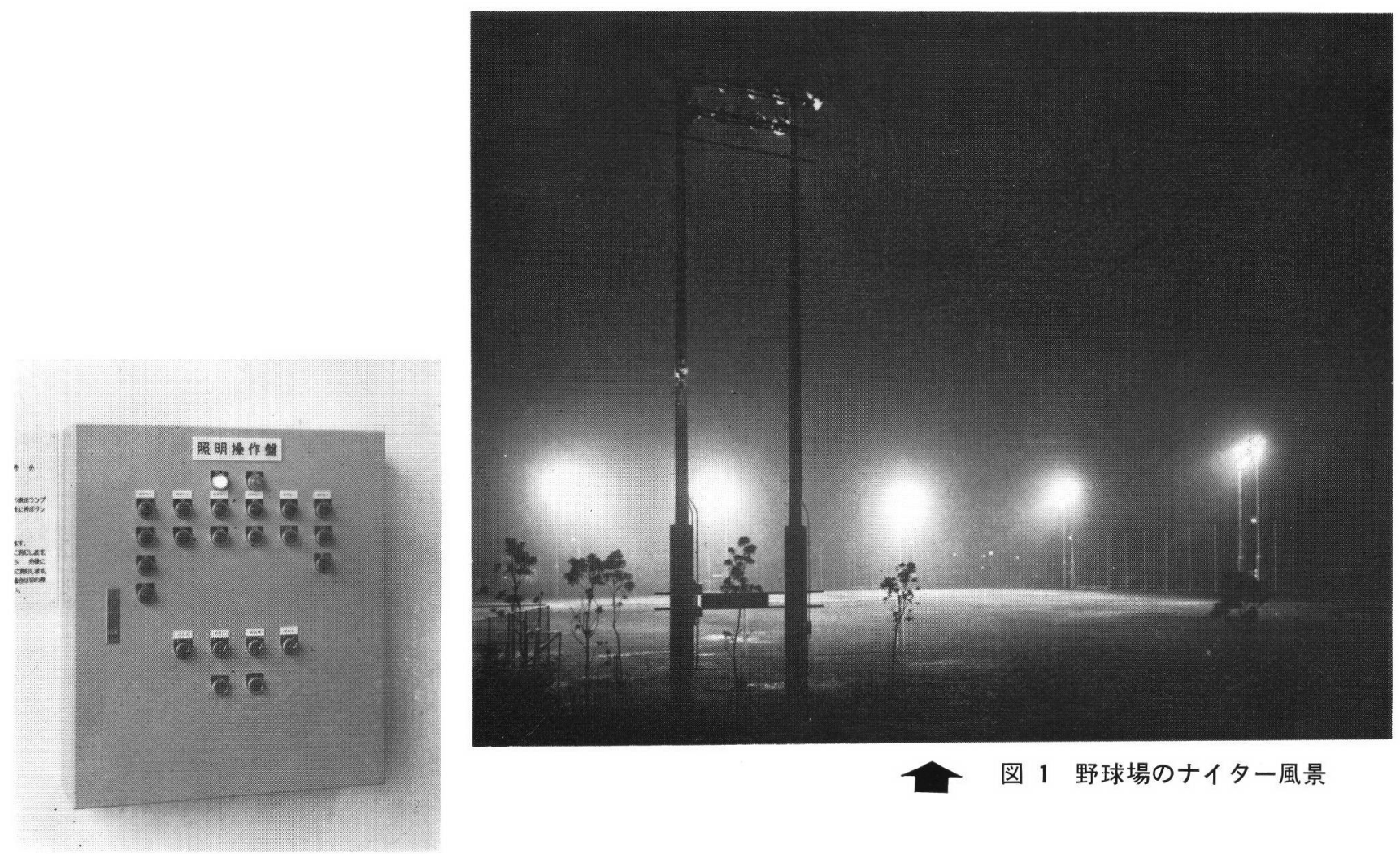

○図 1 野球場のナイター風景

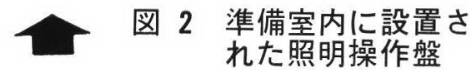

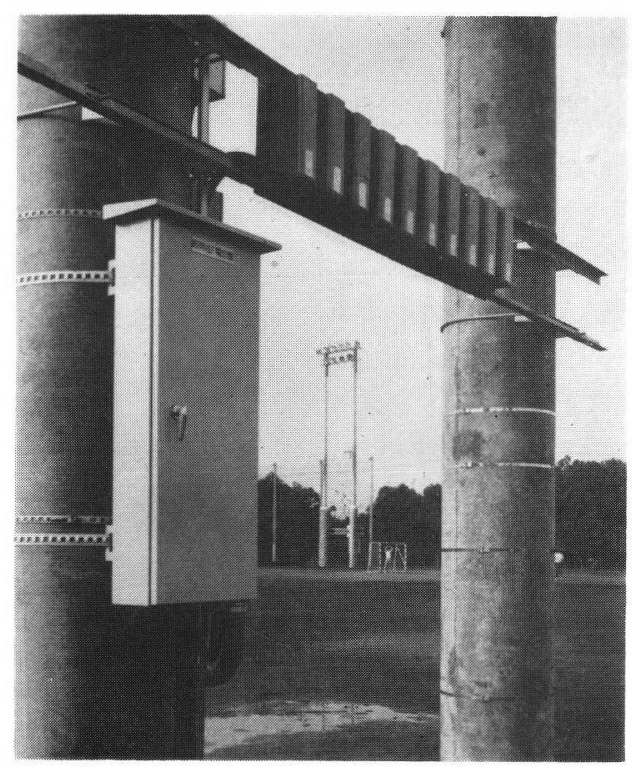

—図 3 照明柱に取り份

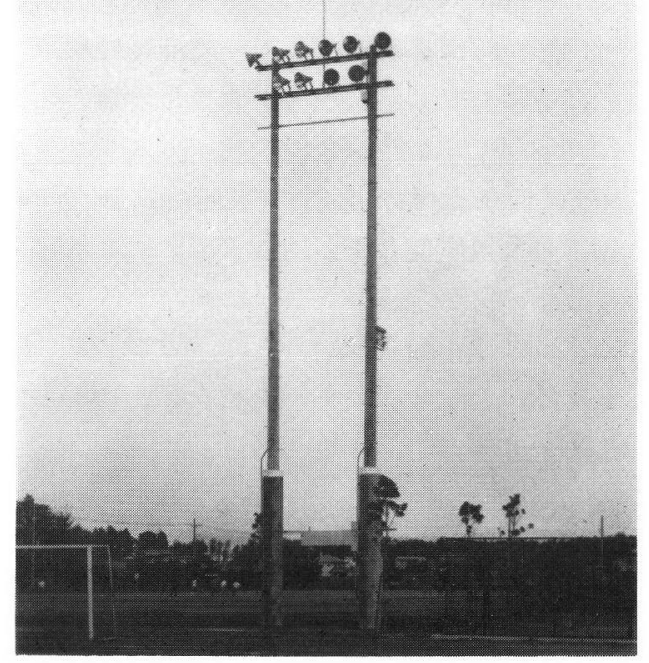

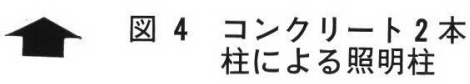




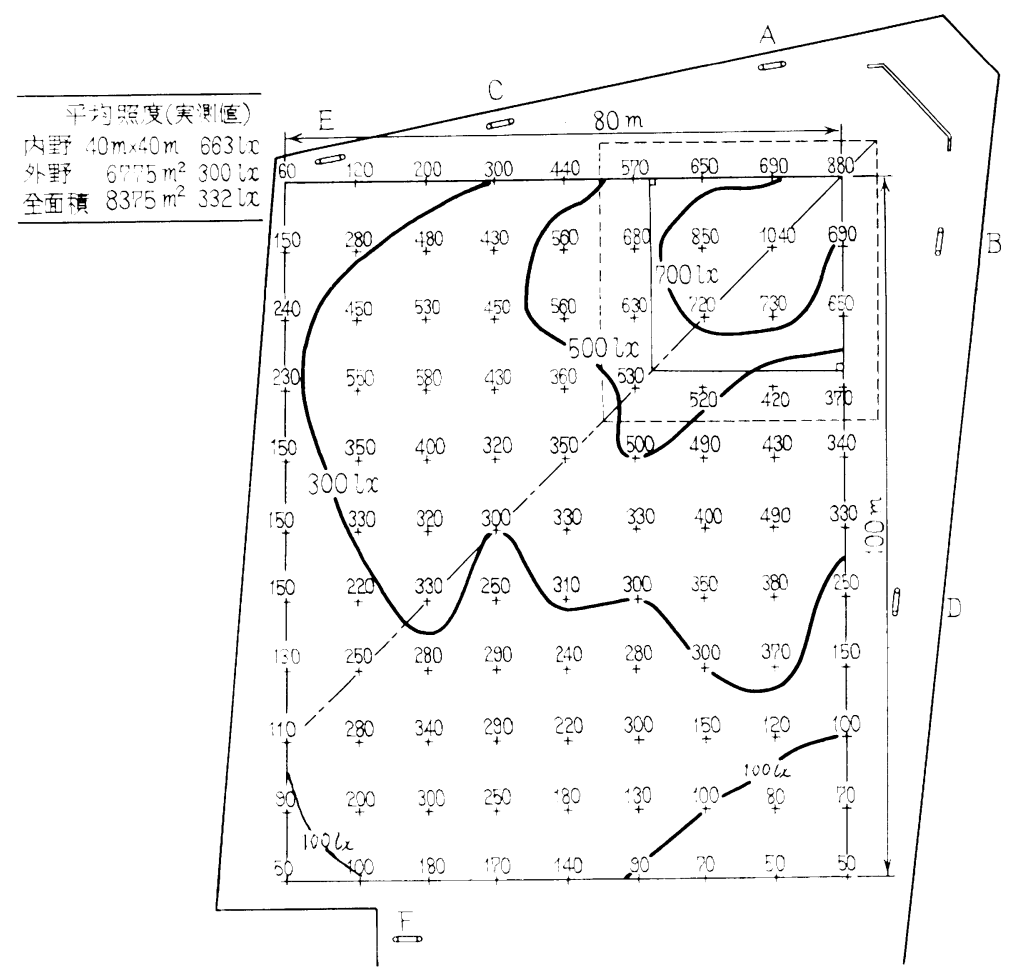

○図 5 野球場の照度分布図（奏測值）

\section{概}

\section{要}

国鉄浮盤線・勝田駅上り北柬へ $2.8 \mathrm{~km}$, 㓮明飞緑豊か

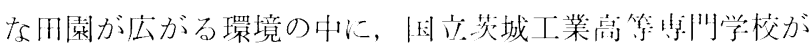
ある。総敷地面積 $101,280 \mathrm{~m}^{2}$ のキャンハスのの将側に広が る連動場（総面積 $30,270 \mathrm{~m}^{2}$ ）は，野球場をはじめ咾上競 技場，テニスコートなどがある。

この汪ど，野球場を夜間に一般市民のスポーツの場とし て㕕く開放する日的から，ナイタ一設借が管成した（図 1).

\section{照 明 設 備}

照明計画にあたり，広く一般市民に利用されることか ら, 省電力でしかも操作が簡単な設储が要求され, 光源に は高効摔で，かつ演色性の良いメタルハライドランブを採 用した。 束た操作方法は，野球場に隣接与る準備案内に設 置された操作盤と，照明柱下部に取り付汀られた電灯盤と の連動により，誰もが容易に操作にできるよらに設計されて いる（図 2, 図 3).

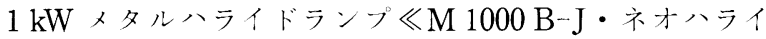

ドランプ》が 10 灯 / 1 集ずつ組又込まれた兴划柱は，灯 具取付计地上 $20 \mathrm{~m}$ (灯具最下段) のコンクリートボ

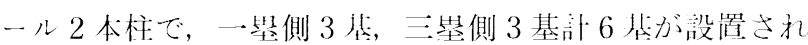
ている。な技，とれぞれの照明柱に電灯盤と電䌘殺虫器が 取り付汀られている（図 4, 表 1）。

照度は, バッテリー間 $880 \mathrm{~lx}$, 内野 $663 \mathrm{~lx}$, 外野 $300 \mathrm{~lx}$ が 起測され，市民野球にも十分な明るさが得られている（図 $5)$.

\begin{tabular}{|c|c|c|c|c|c|c|c|c|}
\hline 灯具（光源） & 照 明 柱 & $\mathrm{A}$ & B & $\mathrm{C}$ & $\mathrm{D}$ & $\mathrm{E}$ & $\mathrm{F}$ & it \\
\hline $\begin{array}{l}\mathrm{HT}-100 \quad 60 \mathrm{M} \\
(\mathrm{M} 1000 \mathrm{~B}-\mathrm{J} /(\mathrm{BH})\end{array}$ & 中角形 & 10 & 10 & 10 & 10 & 5 & 10 & 35 \\
\hline $\begin{array}{l}\mathrm{HT}-100 \quad 60 \mathrm{~W} \\
(\mathrm{M} 1000 \mathrm{~B}-\mathrm{J} /(\mathrm{BH})\end{array}$ & 狭角形 & 0 & 0 & 0 & 0 & 5 & 0 & 5 \\
\hline
\end{tabular}

\begin{tabular}{|c|c|}
\hline 施 & 国立茨城工業高等専門学校 \\
\hline †・監理 & 国立茨城工業帛等専門学校 \\
\hline 6 & 東芝電材秼) \\
\hline
\end{tabular}

竣 I. 昭和 56 年 3 月

（資料提供 茨城工業高等専門学校）

大算根 正昭

（東足電材秼首都圈支店技術営業センター）

専門会員 植田＼cjkstart清 


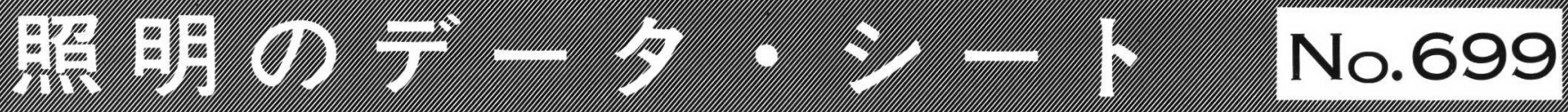

一東京都一

間接照明|手法による

\section{成瀬 プラザビルのプール照明}

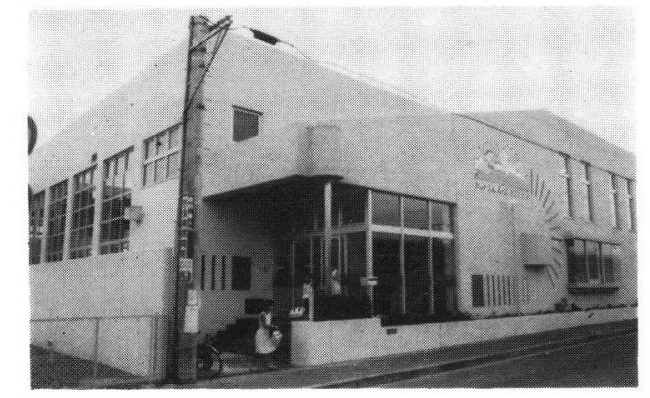

2 図 1 外 観

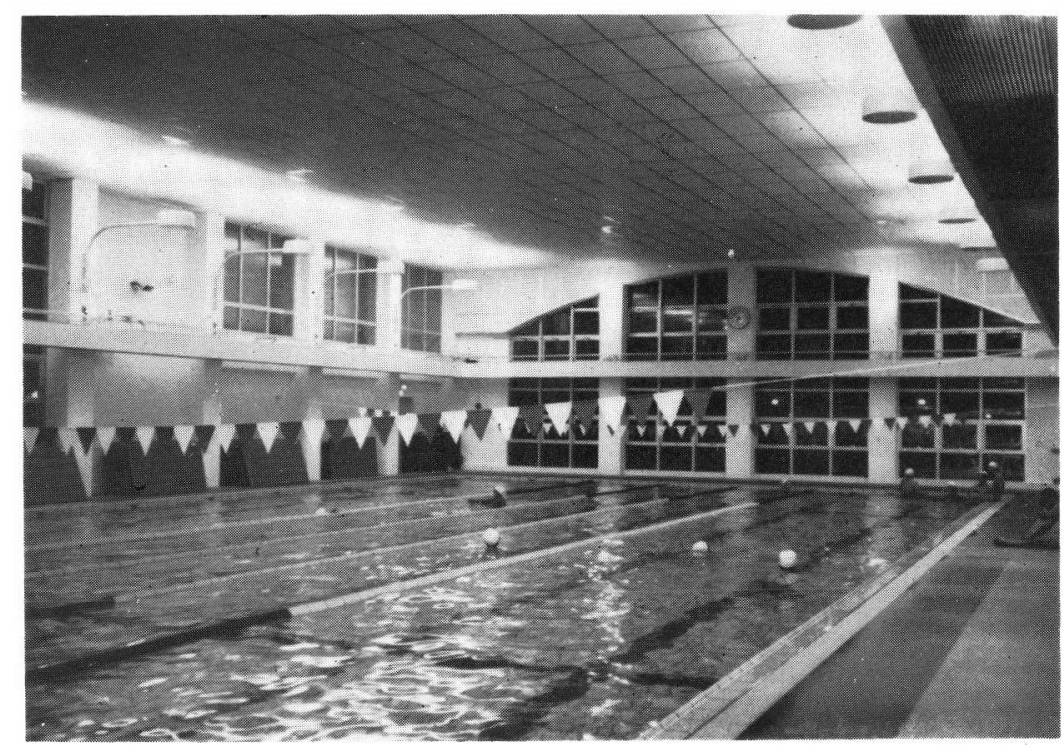

2 図 2 プール（夜間）

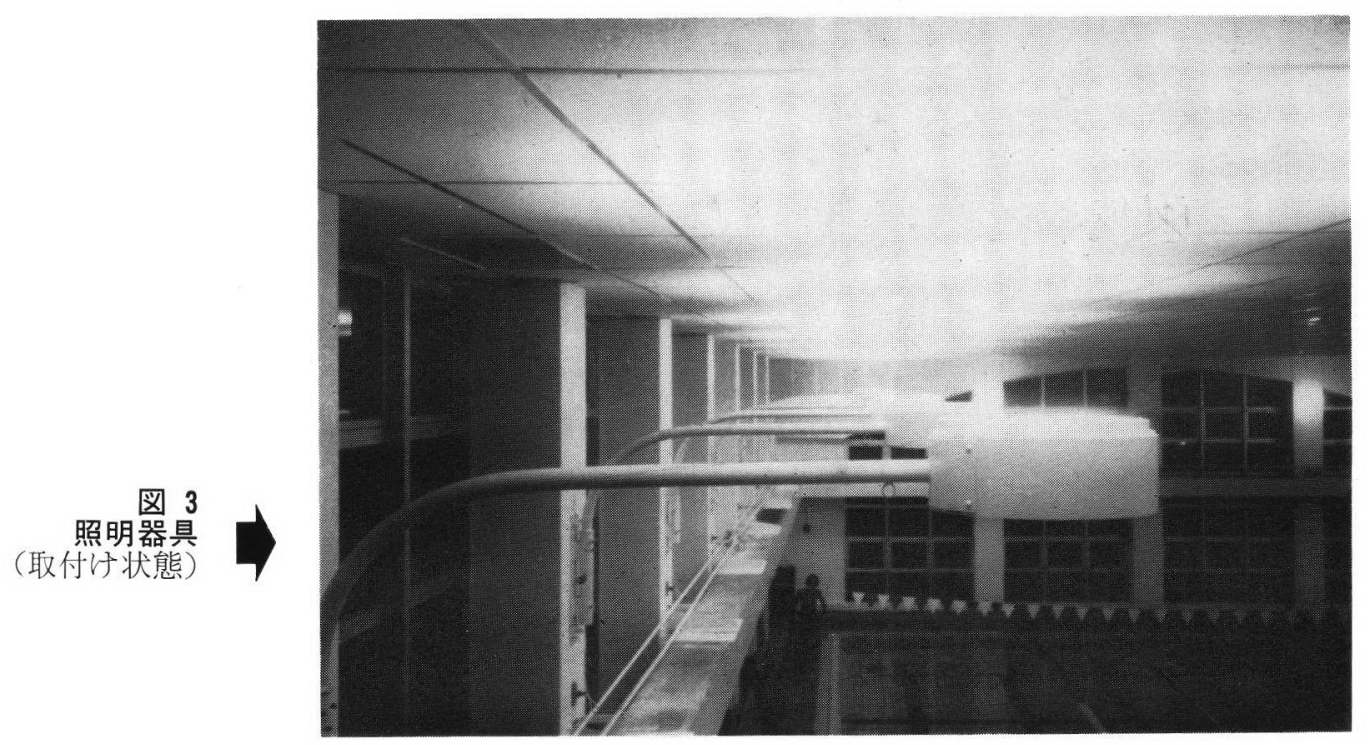




\section{概 要}

昭和56年 6 月町田市成瀬駅前に，屋内温水プールを中心 とした成瀬プラザビルがオープンし，新しいスイミングス クールとして注目されている，このプールは面積約 $550 \mathrm{~m}^{2}$ (プールサイドを含も)， $25 \mathrm{~m} \times 7$ コースの規模で，室内 温度 $32^{\circ} \mathrm{C}$ ，水温 $30^{\circ} \mathrm{C}$ を常に保つことができるスイミング スクール用温水ブールであり, 同ビル内には更衣室, シャ ワー室, コーチ室の汪か、クリニック，店舗，契茶室など を備えている。

\section{照 明 設 備}

スイミングプールとして, 一般の直射形の照明器具で は, 值射グレアの問題はもとより，水面に光源が映り水面 下の見え方を悪化し，捻添れ沈んだ児童などの発見が遅れ る恐れがあり，本施設ではこれらを考慮して HID ランプ を使用した間接照明器具14台を採用した。照明器具は壁面 取付け形で壁面の各柱よりし形のアームで突出させ，開口 部を天井面に向外て，天井面よりの反射光によって間揬照 明を行ならようになっている。

ランプは, 肌色が美しく健康的に見えるよら高演色性人 タルハライドランプ $400 \mathrm{~W} \mathrm{10}$ 台 $\left(R_{a}=90\right)$ 之, 演色改善形 高灰:ナトリウムランプ $360 \mathrm{~W} 4$ 台 $\left(R_{a}=60\right)$ の混光とし, 混光比 $\mathrm{M}: \mathrm{Na}=78: 22$ で色温度 $4600 \mathrm{~K}$, 平均演色評俩 数 $R_{a}=92$ で設計照度は, 練習用水泳プールとしては明る めの $200 \mathrm{~lx}$ （保守率 0.55，哭明率：0.44 亿設定した。ち なみに施亡後の実測值は，头均照度で $3461 \mathrm{x}$ (プール水 面・初期值）老得た。

照明器具注, 尚純度アルミ $(99.85 \%)$ の電解研磨アルマ イト仩上げの皮射板を用い，特にち密な光学没訃に上り形 状を決定しているため，天井面を公い範明で均一に照明で き，器具効准も䯩い(約70\%)。束た屋内プールで使用与 るため，防錆・耐食を考虑して本体拉よびア一ムにはステ ンレス材を用い器具全体を密閉構造とした。

天井而の仕上げは，間接照明方式採用に伴い反射率の高 い耐水等綿吸音板 $(\rho \fallingdotseq 80 \%)$ を使用した。

本施設は, アーム形間接照明器具の採用で, 次の特長が ある。

（1）天井取付计形照明器具に比較して，光源が直接水面 に映らないため水面下の見方方が向上した。

(2) プール面の照度均斉度が良好である（最小／最大= $1 / 2.5)$

（3）照明器具が壁面取り付计で，アームが $90^{\circ}$ 回転でき るためランプ交換, 清掃, 点検などが, 他の取付け方法に くらべ容易となった。

(4) 高演色性メタルハライドランブと，演色改善形宲左 ナトリウムランプの併用により，少ない電力で見え方の良 い照明ができる。

（5）天井面の照明器具をすべて省いたため，全面的に岩 綿吸音板が使用でき，今までのプールと比較して音響効果 が良好になった。

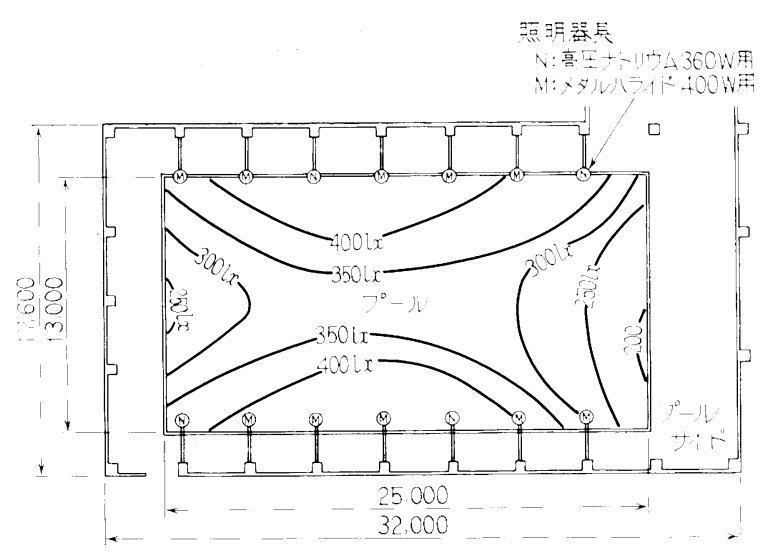

図 4 照度分布図（夹測值）
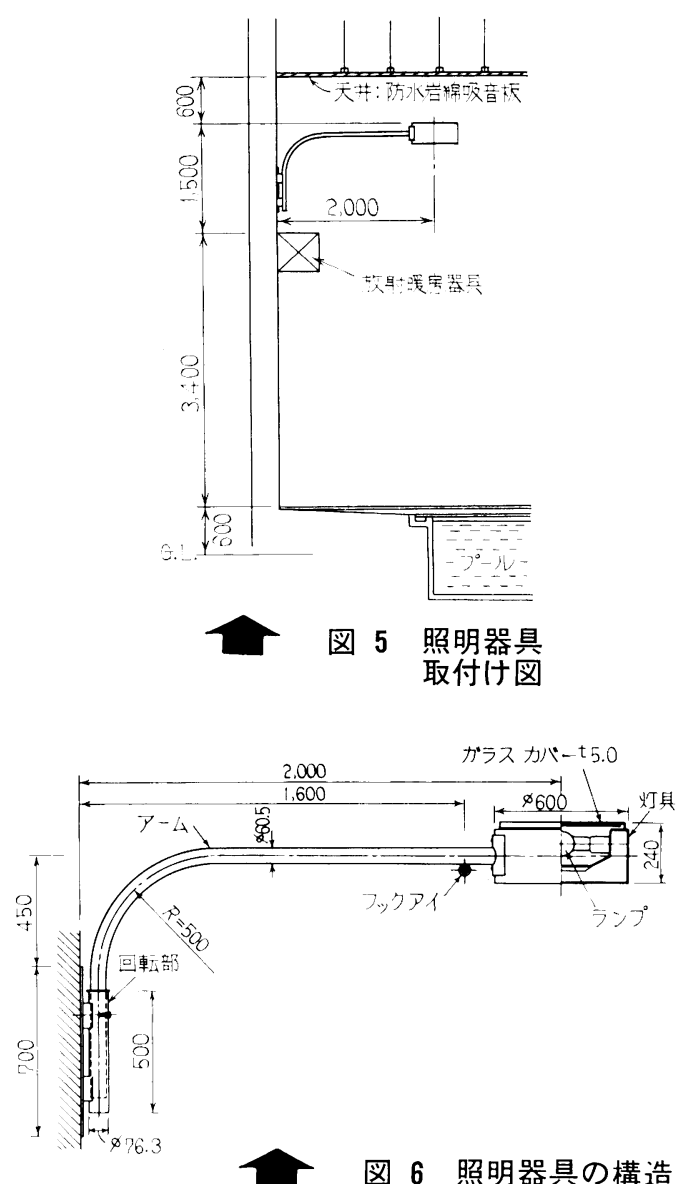

所 在 地

施主七ントラルスイムクラブ成瀬

設計 偢東急設計コンサルタント

施工：東急プレハブ(獭

電気工事秋田電気秼

器具製作 エジソンライティングジャパン

竣

工. 56 年 6 月

（資料提供 秼東急設計コンサルタント) 専門会員 石澤 猛 (エジソンライティングジャパン SPI 技術部) 正会員 小山 博司

(㧣因幡電機製作所 技術部) 正会員川口久美雄 
照明のデータ・シート No.700

一大 阪 府一

マイコンの応用により省人化・即応性・安全性を重視した

\section{国立民俗学博物館講堂の舞台照明}
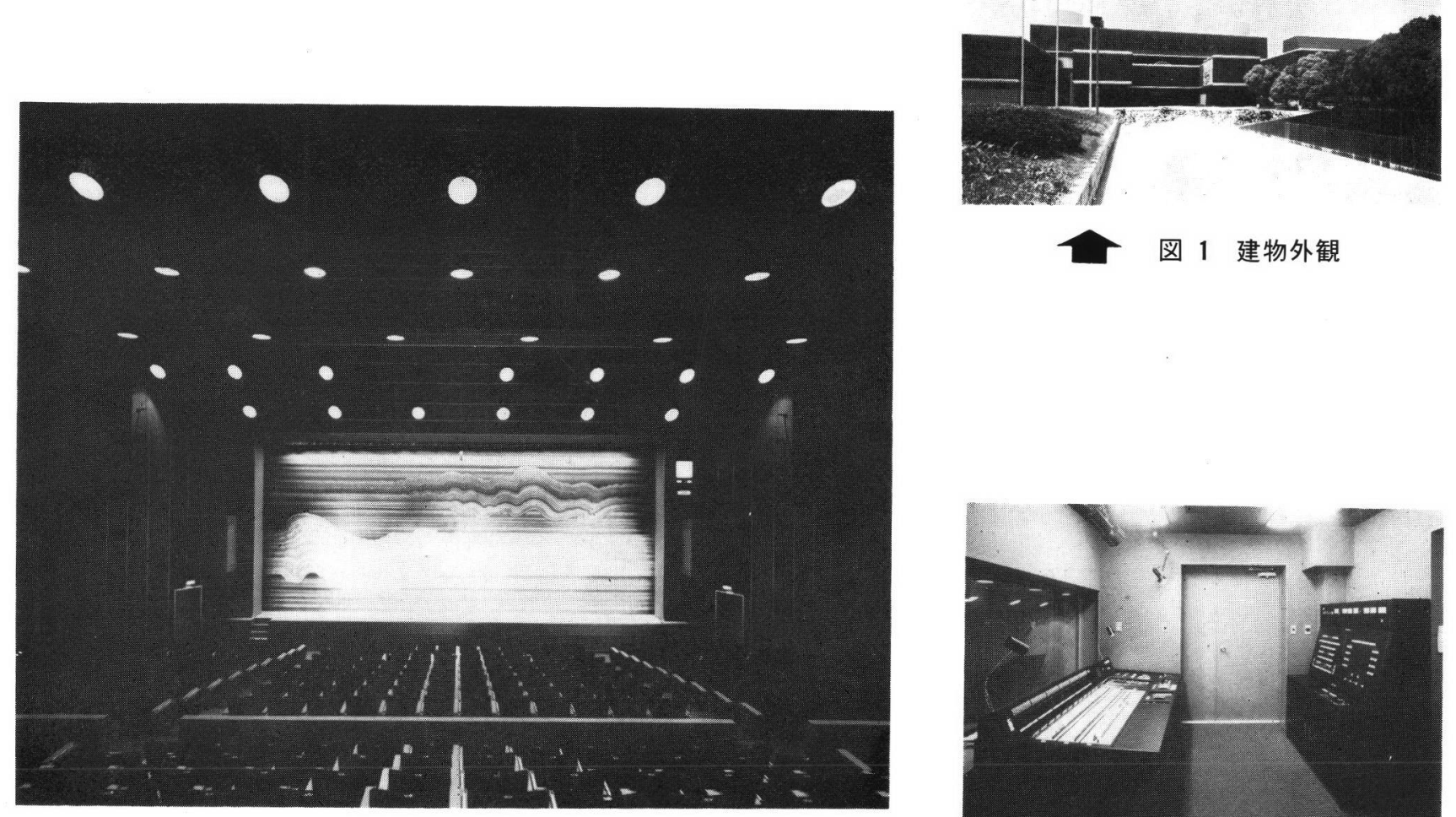

2 図 2 講堂内部
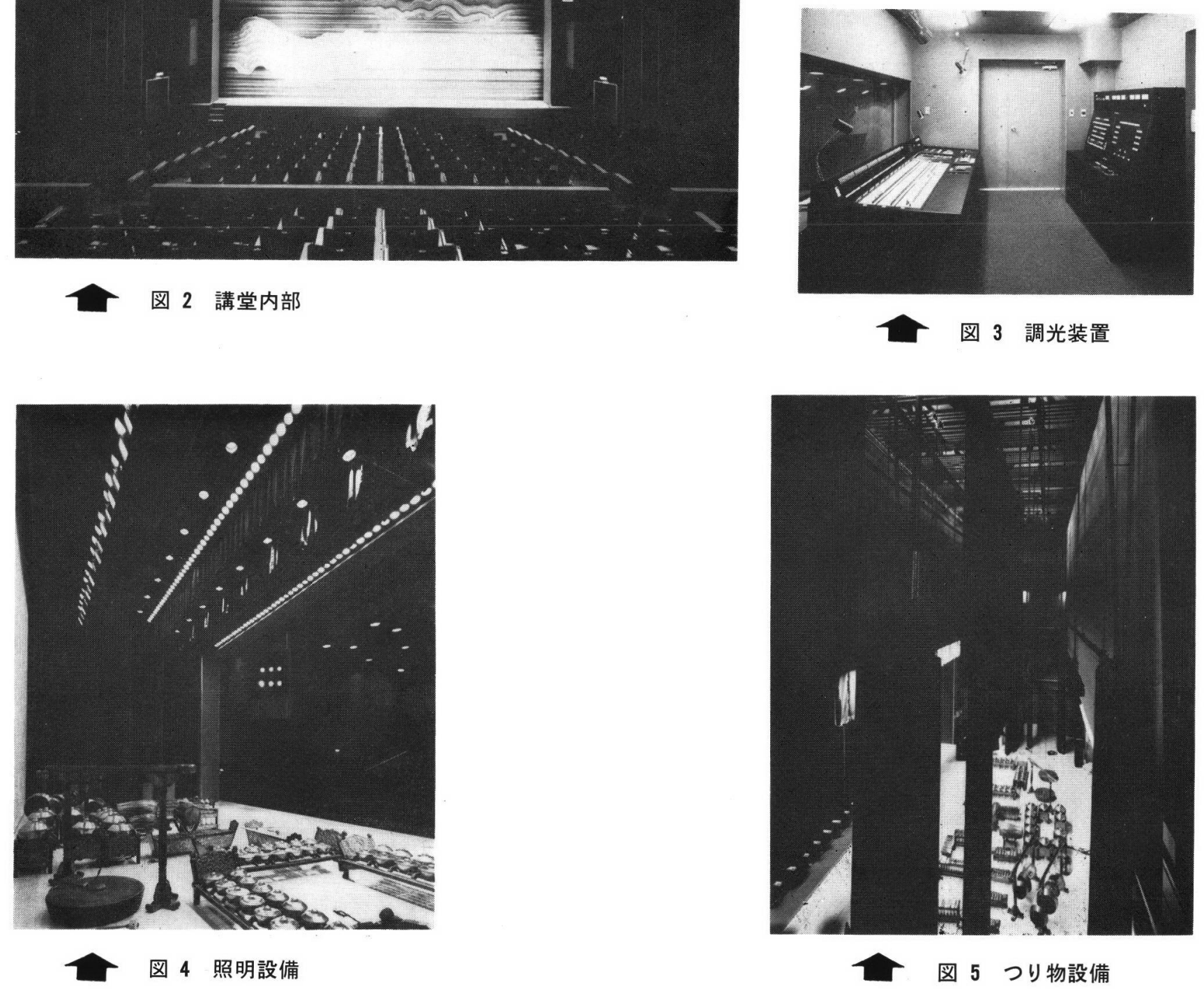

J. Illum. Engng. Inst. Jpn. Vol. 66 No. 51982 


\section{概}

\section{要}

国立民族学博物館は，世界民族の社会や文化を正しく理 解認識しそのルーツを探る施設で，規模・内容において世 界でも類を見ないものである。このたびその機能の一層の 充実をはかるため最新の設備を備えた講堂が完成した。

この講堂は 469 人収容で, 学術講演会, 国際研究集会, 公開講座，民族芸能の公演など多目的に使用される。

今後は, この講堂の活用により内外の研究者との交流を 樑め研究博物領としての活動拡大が期待されている.

舞台規模は，プロセニアム間口 $14 \mathrm{~m}$ ，プロセニアム高さ

$6 \mathrm{~m}$, 舞台奥行 $7.5 \mathrm{~m}$, 舞台 $21 \mathrm{~m}$.

<舞台設備の特長 $>$

（1）調光装置負荷選択に電子クロスバーを採用し， 操作部にはマイコンの導入，および PFG スイッチを電子 化している、舞台袖に設けたリモコン盤にて簡単なシーン 操作ができる.

（2）照明設備 八ロダンランプを主体とし，TV 中継・ 録画撮影にも対応できるようになっている。

(3) つり物設備 ○汪とんどの設備を電動化している ため綱元部がない。○どん帳の昇降スピードは 2 段階に变

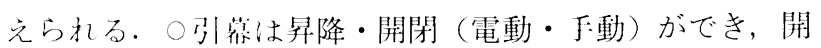
閉スピードも2段階に変えられる. 照明器具への電源供 給は,ヶーブルリールを使用している。

<舞台設備の内容 $>$

（1）調光装置 電源人ノ： $\mathrm{AC}$ 単相 3 線 $100 \mathrm{~V} / 200 \mathrm{~V}$ 2 系統, GAC 単相 3 線 $100 \mathrm{~V} / 200 \mathrm{~V} 60 \mathrm{~Hz}$. 調光出力 : (舞台用) $100 \mathrm{~V}$ 白熱灯 $20 \mathrm{~A}$ 調光二ニット 106 台, 白熱 灯 $30 \mathrm{~A}$ 調光二ニット 14 台, 負荷回路数 120 回路. (客席用) $100 \mathrm{~V}$ 白熱灯 $20 \mathrm{~A}$ 調光二ニット 17 台, 負荷回路数 17 回路.

負荷選扑：電子クロスバー方式. ○イコンを用いて, 調光用フェーダと調光ユニットの接続を電子的に行ない, その組み合わせ接続を記憶することができる。接続組み 合わせの「仕込み」, 「払い」，「実行」，「プレビュー」，「負 荷チェック」などの機能を有している。

操作：（舞台操作部）システムフェーダ 1 , グルーブフ エーダ× 6 , 自動兼手動クロスフェーダ 1 紬, シングルフ ェ一ダ $60 \times 3$ 段，電子 $\mathrm{PFG}$ スイッチ 60 倜．（舞台記憶 部）部憶容量 99 シーン，記憶操作スイッチ 1 組，再生・修 正操作スイッチ 1 組，編集操作スイッチ 1 組.（客席操作 部）マスターフェーダ 1 , シングルフェーダ 3 , 自動押し ぼたんスイッチ 1 組

遠隔操作：（算台部）シーン選択押しぼたん 2 組, マス ターフェーダ $1 \times 2$ 組, シングルフェーダ $3 \times 2$ 組, 作業 灯 $\mathrm{SW} \times 2$. (客席部) 日動押しぼたんスイッチ 1 組.

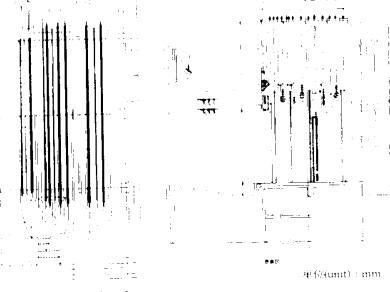

図 6 ステージ部平面図・断面図
（2）照明設備

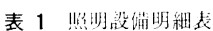

\begin{tabular}{|c|c|c|c|c|}
\hline No. & 记只 & 秒 & 优: & 数量 \\
\hline 1 & P B & プロセニアボーダライト & $200 \mathrm{~W} \times 63 \mathrm{KJ}$ & 1 列 \\
\hline 2 & $1 \mathrm{SUS}$ & 第1+大ペンションフライダク & $\begin{array}{l}20 \mathrm{AT} \Xi ン セ ン ト 24 \text { 湖付き } l= \\
14.4 \mathrm{~m}\end{array}$ & 1 列 \\
\hline & & 间上スポットライトト & $\begin{array}{l}1 \mathrm{~kW} 200 \phi \text { フレネルレンズス } \\
\text { ポット } \\
1 \mathrm{~kW} 200 \phi \text { 平凸レンズスポ产 } \\
\text { 卜 }\end{array}$ & $\begin{array}{l}8 \text { th } \\
4 \text { th }\end{array}$ \\
\hline 3 & $1 \mathrm{~B}$ & 第 1 ボーダライト & $200 \mathrm{~W} \times 72 \mathrm{~kJ}$ & 1 列 \\
\hline 4 & $2 \mathrm{SUS}$ & $\begin{array}{l}\text { 第2サスヘンンシ:ンフライダク } \\
\text { ト } \\
\text { 间トスポットライト }\end{array}$ & 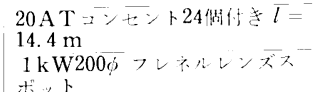 & $\begin{array}{l}1 \text { 列 } \\
8 \text { i }\end{array}$ \\
\hline & & & 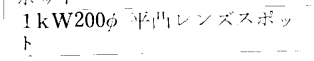 & 4 í \\
\hline 5 & $\mathrm{UH}$ & $\begin{array}{l}\text { アッパーホリゾントフライダク } \\
\text { ト }\end{array}$ & $20 \mathrm{AT}$ エンヒント56湖村き & 1 夘 \\
\hline & & 同上器县 & $500 \mathrm{~W}$ 八ロダンライト & 56 t \\
\hline 6 & BSUS & $\begin{array}{l}\text { バックサスペンンョンフライダ } \\
\text { クト }\end{array}$ & $20 \mathrm{AT}$ Tンヒント16㑑付き & 1 列 \\
\hline 7 & F R S & フロントサイドライト & 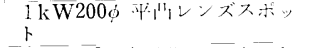 & $12 \nrightarrow \mathrm{t}$ \\
\hline 8 & $\mathrm{CL}$ & シーリングスポットライト & 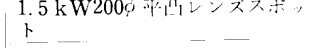 & 27 台 \\
\hline 9 & CPS & センタービンスポットライト & 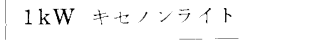 & $1 t i$ \\
\hline 10 & $\mathrm{~F}$ & フントライト & $60 \mathrm{~W} \times 72$ 灯（坤迟又） & 1 列 \\
\hline 11 & $\mathrm{LH}$ & ロアーホりソントライト & $300 \mathrm{~W} \times 4 \mathrm{~kJ}$ & 14 台 \\
\hline \multirow[t]{2}{*}{12} & $\mathrm{~F} \mathrm{C}$ & フロアーコンセント & $\begin{array}{l}20 \mathrm{~A} \times 4 \text { 㑑い } \\
20 \mathrm{~A} \times 3 \text { 湖। }\end{array}$ & $\begin{array}{l}3 \text { 湖 } \\
8 \text { 湖 }\end{array}$ \\
\hline & & & $20 \mathrm{~A} \times 1$ 湖 & 2 \\
\hline 13 & W C & ウナールコンヒント & $60 \mathrm{~A} 1$ 㑬! & 2 做 \\
\hline
\end{tabular}

(3) つり物没備

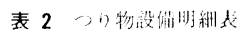

\begin{tabular}{|c|c|c|c|}
\hline t. & 多 & 椂 & \\
\hline 1 & ぞん盿 & 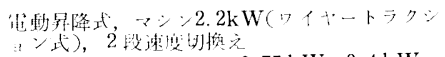 & \\
\hline ᄆ & 前引推 & 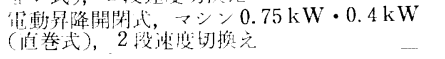 & \\
\hline$>$ & 中割箱 & 菓動開閉式, マンン $0.4 \mathrm{~kW}$ (囬㥕式) & \\
\hline$=$ & スクリーン & 電動昇降式, マンン $2.2 \mathrm{~kW}$ (而炎式) & \\
\hline+ & スクリーンカットマスク & 電動開閉式, マンン0 $2 \mathrm{~kW}$ (们管式) & \\
\hline$\therefore$ & $\therefore$ ○草 & 電動開閉式, マンン $0.4 \mathrm{~kW}$ (们炎代) & \\
\hline 卜 & ホリゾント幕 & 電動昇降式，マンン $1.5 \mathrm{~kW}$ (们炎式) & \\
\hline 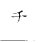 & 炎術バトン & 電動外峰式，マンン $1.5 \mathrm{~kW}$ (们卷式) & \\
\hline ) & 葆佣バトン & 電動烈降武，マシン $1.5 \mathrm{~kW}$ (伯巻式) & \\
\hline z & サイド幕 1 & 電動虾降式，手引開閂 & \\
\hline 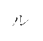 & サイド幕 2 & 手引州脷 & \\
\hline$\Rightarrow$ & 力又、幕 & 照㗅ハトン併没, 固定つ成 & \\
\hline & 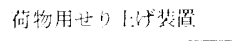 & 電野外降式，マンン $3.7 \mathrm{~kW}$ (ワイヤ卷取心) & \\
\hline & 陪落影外不，卜 & 電物開閉式, マシン $0.4 \mathrm{~kW}$ & \\
\hline
\end{tabular}

所在地

施主：国立民族学博物館

設計黑川糺章建築・都市設計事務沂

監埋国立民族学博物领

建築工事 (侏竹中工務店

装置没備 ナショナル電設粦

竣

工. 炤和56年 5 月

（資料提供 松下電工(敇照明中央 LAB) 専門会員 中矢 清司

(同 照明システム商品事業部)

正会員 所広光 正会員 高橋 邦男 